\title{
Impacts of 1-Methylcyclopropene and Controlled Atmosphere Established during Conditioning on Development of Bitter Pit in 'Honeycrisp' Apples
}

\author{
James P. Mattheis ${ }^{1}$ and David R. Rudell \\ USDA-ARS Tree Fruit Research Laboratory, 1104 N. Western Avenue, \\ Wenatchee, WA 98801

\section{Ines Hanrahan \\ Washington Tree Fruit Research Commission, 105 S. 18th Street Yakima, WA 98901}

Additional index words. Malus $\times$ domestica, ethylene inhibition, rapid CA, fruit quality, physiological disorders, diffuse flesh breakdown, soft scald, soggy breakdown

\begin{abstract}
Honeycrisp' apples are susceptible to develop the physiological disorder bitter pit. This disorder typically develops during storage, but preharvest lesion can also develop. 'Honeycrisp' is also chilling sensitive, and fruit is typically held at 10 $20^{\circ} \mathrm{C}$ after harvest for up to 7 days to reduce development of chilling injury (CI) during subsequent cold storage. This temperature conditioning period followed by a lower storage temperature $\left(2-4{ }^{\circ} \mathrm{C}\right)$ reduces $\mathrm{CI}$ risk but can exacerbate bitter pit development. Bitter pit development can be impacted in other apple cultivars by the use of controlled atmosphere (CA) storage and/or 1-methylcyclopropene (1-MCP). Studies were conducted to evaluate efficacy of CA and/or 1-MCP to manage 'Honeycrisp' bitter pit development. Apples from multiple lots, obtained at commercial harvest, were held at $10{ }^{\circ} \mathrm{C}$ for 7 days and then cooled to $3{ }^{\circ} \mathrm{C}$. Half the fruit was exposed to $42 \mu \mathrm{mol} \cdot \mathrm{L}^{-1}$ 1-MCP the day of receipt while held at $10^{\circ} \mathrm{C}$. Fruit were stored in air or $\mathrm{CA}(3 \mathrm{kPa} \mathrm{O}$, $0.5 \mathrm{kPa} \mathrm{CO}$ for 2 days, then $1.5 \mathrm{kPa} \mathrm{O}_{2}, 0.5 \mathrm{kPa} \mathrm{CO}_{2}$ ) established after 1 day at $10^{\circ} \mathrm{C}$ or after 7 days at $10^{\circ} \mathrm{C}$ plus 2 days at $3{ }^{\circ} \mathrm{C}$. Fruit treated with 1-MCP and/or stored in CA developed less bitter pit compared with untreated fruit stored in air, and bitter pit incidence was lowest for 1-MCP-treated fruit with $\mathrm{CA}$ established during conditioning. Development of diffuse flesh browning (DFB) and cavities, reported to occur during 'Honeycrisp' CA storage, was observed in some lots. Incidence of these disorders was not enhanced by establishing CA 2 days compared with 9 days after harvest. 1-MCP and CA slowed peel color change, loss of soluble solids content (SSC) and titratable acidity (TA), and reduced ethylene production and respiration rate. The results indicate potential for the postharvest management of bitter pit development in 'Honeycrisp' apple through use of 1-MCP and/or CA storage.
\end{abstract}

High consumer demand for 'Honeycrisp' apples has supported a favorable price structure for producers (Warner, 2012) despite production and postharvest challenges across production regions (Tong, 2016). One of the challenges is managing susceptibility to bitter pit (Bedford, 2001; Rosenberger et al.,

\footnotetext{
Received for publication 21 Sept. 2016. Accepted for publication 3 Nov. 2016.

Financial support for this research was received from AgroFresh, Inc. and the Washington Tree Fruit Research Commission.

We thank Karen Blaedow, Janie Countryman, Brenda Steady, Liana Suryaningsih, Amanda Drehmer Vieira, and Marcelo Vieira for excellent technical assistance.

Mention of trade names or commercial products in this publication is solely for the purpose of providing specific information and does not imply recommendation or endorsement by the U.S. Department of Agriculture.

${ }^{1}$ Corresponding author. E-mail: james.mattheis@ ars.usda.gov.
}

2001). Bitter pit symptoms include brown, dry areas typically just below the peel, typically ranging in size from 1 to $5 \mathrm{~mm}$ with adjacent peel also brown. Fruit nutrient content (Rosenberger et al., 2004; Telias et al., 2006), fruit maturity at harvest (Prange et al., 2011), fruit size (Prange et al., 2011; Telias et al., 2006), and crop load (Telias et al., 2006) are factors that impact risk of bitter pit development. Preharvest calcium application (Biggs and Peck, 2015; Peryea et al., 2007; Rosenberger et al., 2004), crop load management (DeLong et al., 2006; Robinson and Lopez, 2012), and harvest maturity management (Prange et al., 2011) can contribute to reduced bitter pit development on the tree and during subsequent storage.

Bitter pit symptoms are often absent at harvest and develop during the postharvest period in storage (Ferguson and Watkins, 1989; McAlpine, 1912). Storage in a lowoxygen CA can reduce bitter pit development (Hewett, 1984; Sharples, 1982; Webster and Forsyth, 1979) while impacts of postharvest
1-MCP application have been mixed (Calvo and Candan, 2010; Gago et al., 2015; Mirzaee et al., 2015).

'Honeycrisp' is also chilling sensitive with both peel (soft scald) and cortex (soggy breakdown) tissues at risk of injury development during cold storage (Watkins et al., 2004). Chilling sensitivity is influenced by orchard environment before harvest (Lachapelle et al., 2013; Moran et al., 2009) and fruit maturity at harvest (Watkins et al., 2005). CI risk can be reduced by preharvest application of 1-MCP (DeEll and Ehsani-Moghaddam, 2010) and postharvest temperature conditioning (DeLong et al., 2006; Moran et al., 2009; Watkins et al., 2004).

CA storage of 'Honeycrisp' can provide some reduction in the rate of fruit ripening (Contreras et al., 2014; DeEll et al., 2015; DeLong et al., 2006; Watkins and Nock, 2012) as can postharvest application of 1MCP (Contreras et al., 2014; DeEll, 2010; DeEll et al., 2015; Watkins and Nock, 2012). CA conditions have also been reported to increase the risk of internal disorders resembling $\mathrm{CO}_{2}$ injury including DFB and cavities (Contreras et al., 2014; DeEll et al., 2015; Watkins and Nock, 2012). Disorder development is reduced with increased prestorage conditioning temperature, with prestorage diphenylamine application (Contreras et al., 2014), or by delayed establishment of CA conditions (DeEll et al., 2016). However, delaying CA storage can enhance development of other disorders including bitter pit and peel blotch (DeEll et al., 2016). Postharvest 1-MCP application can also enhance the development of $\mathrm{CO}_{2}$ injury for fruit stored in CA (Lum et al., 2016; Watkins and Nock, 2012).

Although 'Honeycrisp' is susceptible to postharvest disorders that are exacerbated by $\mathrm{CA}$, few incidents of CA injury have been reported in the U.S. Pacific Northwest (I. Hanrahan and J.P. Mattheis, personal communication) where 1-MCP and $\mathrm{CA}$ are widely used for 'Honeycrisp'. As an exploration of the potential for postharvest CA and 1-MCP protocols to address bitter pit, the objective of this study was to assess impacts of 1-MCP and CA imposed during or after temperature conditioning of 'Honeycrisp' on bitter pit development and fruit quality.

\section{Materials and Methods}

Plant material. 'Honeycrisp' (Malus $\times$ domestica Borkh.) apples were obtained from five commercial orchards in central Washington State over three harvest seasons (2013-15). Apples were commercially mature as determined by the grower and were obtained in bulk bins the day of harvest. Apples absent of external defects were placed onto pressed fiber trays and the trays placed into cardboard boxes. Packed boxes were moved into one of two storage rooms at $10{ }^{\circ} \mathrm{C}$, one for controls, the other for 1-MCP treatment. Fruit were exposed to $42 \mu \mathrm{mol} \cdot \mathrm{L}^{-1}$ 1-MCP (AgroFresh, Inc., Spring House, PA) in an 800-L metal cabinet for 
$16 \mathrm{~h}$. The chamber was opened at the end of the treatment period, and $4 \mathrm{~h}$ later, boxes were removed from the treatment chamber and transferred to the other $10{ }^{\circ} \mathrm{C}$ storage room. All fruit was held for $7 \mathrm{~d}$ at $10{ }^{\circ} \mathrm{C}$ and then the room temperature was reduced to $3{ }^{\circ} \mathrm{C}$. For CA storage, fruit on trays were placed into $0.14-\mathrm{m}^{3}$ chambers and a CA of $3 \mathrm{kPa} \mathrm{O}_{2}$ and $0.5 \mathrm{kPa} \mathrm{CO}_{2}$ was established $24 \mathrm{~h}$ after receipt (CA $1 \mathrm{~d}$ ) or after an additional $8 \mathrm{~d}$ (CA $9 \mathrm{~d}$ ) consisting of $6 \mathrm{~d}$ at $10{ }^{\circ} \mathrm{C}$ then $2 \mathrm{~d}$ at $3{ }^{\circ} \mathrm{C}$. Two days after CA establishment, $\mathrm{O}_{2}$ was reduced to $2 \mathrm{kPa}$. Static CA gas concentrations were established using $\mathrm{N}_{2}$ generated from a membrane gas separator (Permea, St. Louis, $\mathrm{MO}$ ), and air and $\mathrm{CO}_{2}$ from compressed gas cylinders. CA chamber gas concentrations were assessed and adjusted as needed using a commercial control system (Empire Controls, Chelan, WA).

Harvest maturity and fruit quality assessment. Starch content was rated visually using a 1-6 scale (Hanrahan, 2012) on 18 fruit at harvest after staining an equatorial section with a $30-\mathrm{mm}$ solution of I-KI. Peel hue was measured on each fruit at a disorderfree location with minimal red color with a chromameter (CR-300, Minolta, Japan) using CIE illuminant C. Values were converted to hue as described by Hunter and Harold (1987). Firmness was measured on two pared surfaces at the equator of each fruit with a MTD1 analyzer (Mohr and Associates, Richland, WA) fitted with an 11-mmdiameter probe. SSC and TA were assessed using freshly prepared juice from nine replicates (prepared by combining juice from two fruit) per storage treatment combination using a refractometer (Atago N1; Atago, Tokyo, Japan) and a TIM850 titrator (Radiometer, Lyon, France), respectively. Juice was titrated to $\mathrm{pH} 8.2$ using $0.1 \mathrm{~N} \mathrm{KOH}$. Internal ethylene concentration (IEC) was analyzed as described previously (Lumpkin et al., 2014). Ethylene and $\mathrm{CO}_{2}$ were analyzed in gas samples obtained from four replicates of five fruit held in 3.79-L glass jars sealed with teflon lids with two gas ports. Jars were purged with air at $1.76 \mathrm{~mL} \cdot \mathrm{s}^{-1}$ for $1 \mathrm{~h}$, then $1 \mathrm{~mL}$ gas samples were collected from the outlet port and analyzed using a Hewlett Packard 5890 gas chromatograph (Agilent, Palo Alto, CA) equipped with a $0.5-\mathrm{m}, 3.2-$ $\mathrm{mm}$-i.d. stainless steel column packed with Porapak Q (Supelco, Bellefonte, PA), a methanizer (John Booker \& Co., Austin, TX), and a flame ionization detector. The $\mathrm{N}_{2}$ carrier, $\mathrm{H}_{2}$, and air flows were $0.5,0.5$, and $5 \mathrm{~mL} \cdot \mathrm{s}^{-1}$, respectively. Oven, injector, and detector temperatures were 35,100 , and $300{ }^{\circ} \mathrm{C}$, respectively. The methanizer temperature was $290{ }^{\circ} \mathrm{C}$ controlled by an Instrumentation Temperature Controller (Valco Instruments, Inc., Houston, $\mathrm{TX}$ ) with a $\mathrm{H}_{2}$ flow of 0.5 $\mathrm{mL} \cdot \mathrm{s}^{-1}$.

Fruit disorders (bitter pit, peel blotch, DFB, cavitation, soft scald, soggy breakdown, and greasiness) were reported as incidence. Bitter pit was identified as surface lesions $<5 \mathrm{~mm}$ in diameter with underlying brown, corky tissue. Irregularly shaped peel areas of rough, brown tissue $>5 \mathrm{~mm}$ were considered peel blotch (Fig. 1). Brown internal tissues outside the core with diffuse, brown to grayish color were considered DFB. Soft scald and soggy breakdown were rated based on symptoms described previously (Watkins et al., 2004). In years 1 and 2, external disorders were assessed while fruit $(\mathrm{n}=72$, year $1 ; \mathrm{n}=108$, year 2$)$ was in cold storage at 1, 2, 3 (year 2 only), 4, and 7 months after harvest. At 7 months in all years, fruit were removed from storage and held $7 \mathrm{~d}$ at $20{ }^{\circ} \mathrm{C}$ before further analyses. The combined incidence of bitter pit, peel blotch, $\mathrm{DFB}$, and cavity development is reported as total non-chilling disorders and represents the percentage of fruit in each 1-MCP/ atmosphere combination with at least one of these disorders.

Experimental design and statistical analysis. The experiment was conducted using a completely random design with three replicates of six individual fruit at harvest and for each $1-\mathrm{MCP} /$ storage atmosphere combination. All statistical analyses were conducted using SAS 9.4 (SAS Institute, Raleigh, NC). Disorder incidence data (percentage) was arcsine square root transformed before analysis. Significant treatment differences for fruit quality attributes and storage disorders were identified using analysis of variance and treatment means separated using Tukey's honestly significant difference, $P<0.05$, 0.01 , or 0.001 .

\section{Results}

At harvest, all lots had IEC values greater than $0.07 \mathrm{mmol} \cdot \mathrm{m}^{-3}, 4.5 \mathrm{starch}$ rating, $54 \mathrm{~N}$, $98^{\circ} \mathrm{h}, 0.522 \% \mathrm{TA}$, and $11.6 \%$ SSC (Table 1 ). Bitter pit symptoms typically developed within 1 month of harvest as shown for lot A (Fig. 2) and changed little if any after 2 months.

Bitter pit incidence in lot A was $17 \%$ or higher and was impacted by atmosphere and $1-\mathrm{MCP}$ in year 1 and by an atmosphere $\times 1$ MCP interaction in year 2 (Table 2 ). In year 1 , fruit stored in air and 1-MCP-treated fruit with $\mathrm{CA}$ established during conditioning developed the most and least bitter pit during storage, respectively. In year 2, the most bitter pit was found on control fruit stored in air or in CA established after conditioning, while the least bitter pit was found on fruit where CA was established during conditioning. All 1-MCP-treated fruit had similar bitter pit incidence. Bitter pit incidence in lot B was $17 \%$ or lower with no treatment interactions in either year but a main effect for atmosphere in year 2 (Table 3). Fruit with CA established during conditioning had the lowest incidence in year 2. Lot $\mathrm{C}$ fruit had $15 \%$ or less bitter pit and a main effect for atmosphere (Table 4). Bitter pit incidence in lot D was $41 \%$ or less with main effects for atmosphere and 1-MCP. Lot $\mathrm{E}$ had $18 \%$ bitter pit incidence or less with a main effect for atmosphere.

Peel blotch developed on control as well as 1-MCP-treated fruit. An atmosphere $\times 1$ MCP interaction was present for lots A (year 1) and $\mathrm{D}$ with incidence highest in 1-MCP fruit stored in air and no disorder incidence for control fruit stored in air or CA established $9 \mathrm{~d}$ after initiation of conditioning. A 1-MCP main effect was present for lots A (year 2), B (year 1), and C. In all cases, fruit with peel blotch also developed bitter pit, but bitter pit was not always accompanied by peel blotch.

All lots developed DFB but incidence did not exceed $10 \%$. An atmosphere main effect for DFB was present for lot A, and in year 1 establishment of CA $1 \mathrm{~d}$ after harvest resulted in a lower incidence compared with fruit stored in air. In year 2, fruit stored in air had less DFB compared with fruit stored in CA. There were no treatment effects for lots $\mathrm{B}, \mathrm{C}, \mathrm{D}$, or $\mathrm{E}$ as DFB incidence was $4 \%$ or less. Cavity development also occurred in all lots with the highest incidence value of $18 \%$. For lots $\mathrm{A}$ and $\mathrm{B}$, an atmosphere $\times 1-\mathrm{MCP}$ interaction was present in year 2 . The only lot A fruit with cavities were 1-MCP-treated and stored in $\mathrm{CA}$, whereas the only lot $\mathrm{B}$ fruit that

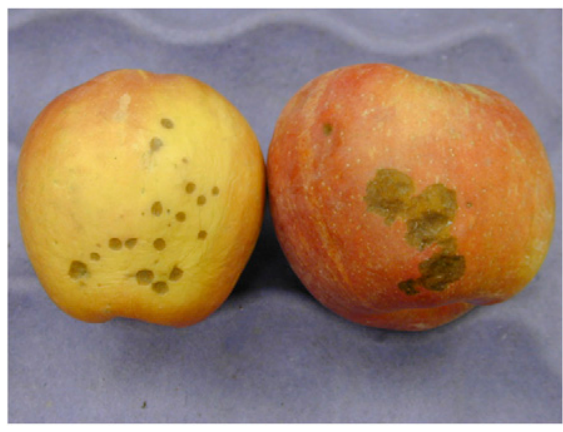

Fig. 1. Bitter pit (left apple) and peel blotch (right apple) symptoms on 'Honeycrisp' apples.

Table 1. 'Honeycrisp' fruit maturity at harvest for five orchard lots harvested in three consecutive years.

\begin{tabular}{lccccccc}
\hline Lot & Yr & IEC $\left(\mathrm{mmol} \cdot \mathrm{m}^{-3}\right)$ & Starch $(1-6)$ & Firmness $(\mathrm{N})$ & Peel $\left({ }^{\circ} \mathrm{h}\right)$ & TA $(\%)$ & SSC $(\%)$ \\
\hline A & 1 & $0.21 \pm 0.08$ & $4.9 \pm 0.2$ & $65.9 \pm 1.6$ & $104 \pm 2.0$ & $0.640 \pm 0.016$ & $13.8 \pm 0.2$ \\
& 2 & $0.52 \pm 0.20$ & $4.6 \pm 0.2$ & $61.6 \pm 1.5$ & $103 \pm 1.2$ & $0.530 \pm 0.020$ & $14.4 \pm 0.3$ \\
B & 1 & $0.50 \pm 0.12$ & $5.3 \pm 0.1$ & $57.9 \pm 1.0$ & $108 \pm 1.0$ & $0.841 \pm 0.037$ & $11.7 \pm 0.1$ \\
& 2 & $0.20 \pm 0.06$ & $5.0 \pm 0.1$ & $63.2 \pm 1.5$ & $104 \pm 1.9$ & $0.523 \pm 0.018$ & $13.5 \pm 0.1$ \\
C & 3 & $0.53 \pm 0.18$ & $5.2 \pm 0.2$ & $54.7 \pm 1.2$ & $103 \pm 1.8$ & $0.648 \pm 0.020$ & $14.0 \pm 0.1$ \\
D & 3 & $0.08 \pm 0.02$ & $5.0 \pm 0.1$ & $55.2 \pm 0.9$ & $105 \pm 1.4$ & $0.549 \pm 0.010$ & $12.7 \pm 0.1$ \\
E & 3 & $0.30 \pm 0.09$ & $5.8 \pm 0.1$ & $56.5 \pm 0.9$ & $98 \pm 2.5$ & $0.529 \pm 0.011$ & $13.2 \pm 0.1$ \\
\hline
\end{tabular}

IEC $=$ internal ethylene concentration; TA $=$ titratable acidity; $\mathrm{SSC}=$ soluble solids content. Values are means $\pm \mathrm{SE}$.

Values are means \pm standard error, $n=18$ [IEC, starch pattern index, firmness, peel hue $\left.\left({ }^{\circ} \mathrm{h}\right)\right], \mathrm{n}=9$ (TA, SSC). 
did not have cavities was stored in air without 1-MCP treatment. Lots B (year 1) and C had an atmosphere main effect where fruit stored in CA had higher incidence compared with fruit stored in air.

The combined incidence of bitter pit, $\mathrm{DFB}$, and cavity development was within $5 \%$ of that for bitter pit for most treatment combinations for lots A, C, D, and E. Exceptions were lot $\mathrm{A}$ in year 2 where $10 \%$ of the fruit stored in CA following 1-MCP application had DFB and/or cavities compared with $17 \%$ that had bitter pit alone; lot B in year 1 where all treatment combinations except air control had $5 \%$ or more combined disorder incidence compared with bitter pit alone; lot $\mathrm{B}$ in year 2 where control CA after 1 or $9 \mathrm{~d}$ had greater than 5\% more disorders compared with bitter pit alone. The increased total incidence of bitter pit, DFB, and cavities was typically due to cavity development also in fruit not having bitter pit.

Soft scald and soggy breakdown incidence were low, and consistent treatment effects were not observed. Peel greasiness was affected by atmosphere (lot A in year 2, lot $\mathrm{E}$ ) or atmosphere $\times 1$-MCP (lot B in year 2) where fruit stored in air had the highest incidence.

Peel hue was lower (yellower) in fruit stored in air for all lots. CA established $1 \mathrm{~d}$ after harvest resulted in the highest or among the highest peel hue values for lots C, D, and E with fruit stored in air having lower values. For all lots, an atmosphere $\times 1$-MCP interaction existed for SSC with control fruit stored in air having the lowest or among a group with the lowest values. Lots $\mathrm{A}-\mathrm{D}$ had an atmosphere $\times$ 1-MCP interaction for TA with CA $1 \mathrm{~d}$ after receipt having the highest or among the

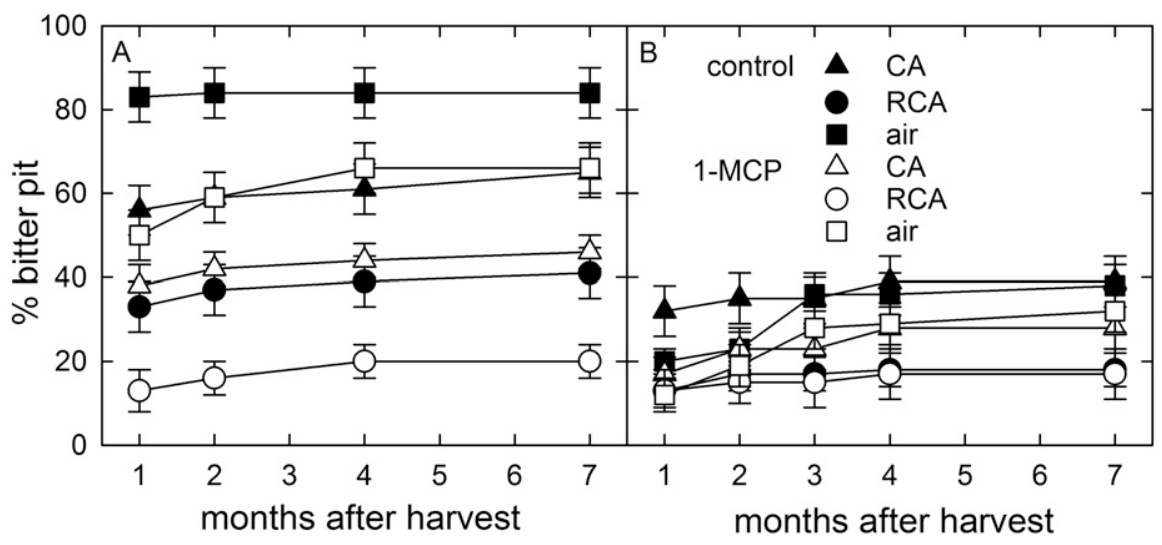

Fig. 2. 'Honeycrisp' bitter pit incidence after harvest. Fruit from lot A (A) year 1 and (B) year 2 at $10^{\circ} \mathrm{C}$ were exposed to 0 or $4.2 \mu \mathrm{mol} \cdot \mathrm{L}^{-1} 1$-methylcyclopropene (1-MCP) for $16 \mathrm{~h}$. Apples were stored in air or a controlled atmosphere (CA) established 1 or $9 \mathrm{~d}$ after 1-MCP exposure. Storage temperature was decreased to $3{ }^{\circ} \mathrm{C} 7 \mathrm{~d}$ after receipt. Values are means $(\mathrm{n}=72$, year $1 ; \mathrm{n}=108$, year 2$) \pm \mathrm{SE}$. highest values. There were no treatment effects for firmness. Ethylene production (lots A, $\mathrm{B}$, and $\mathrm{C}$ ) and IEC (lots $\mathrm{D}, \mathrm{E}$, and F) were lowest or among the lowest for fruit treated with 1-MCP then stored in CA. Storing non-1$\mathrm{MCP}$ fruit in CA also reduced ethylene production or IEC. Respiration rate was also reduced by $1-\mathrm{MCP}$ treatment and CA storage with an atmosphere $\times 1-\mathrm{MCP}$ interaction for lot A (year 1; CA $1 \mathrm{~d}+1$-MCP lowest value, control air and CA $9 \mathrm{~d}+1-\mathrm{MCP}$ highest values) and lot $\mathrm{B}$ (year 2; control air highest value, $1-\mathrm{MCP}+\mathrm{CA} 1 \mathrm{~d}$ or CA $9 \mathrm{~d}$ lowest values). Main effects for atmosphere and 1MCP existed for lot A in year 2 and lot $\mathrm{B}$ in year 1.

\section{Discussion}

Reduced bitter pit development in 'Honeycrisp' apple when fruit were stored in CA rather than air is consistent with previous research for other cultivars (Hewett, 1984; Sharples, 1982; Webster and Forsyth, 1979) but not in 'Honeycrisp' where bitter pit incidence exceeded $40 \%$ in air-stored fruit (Contreras et al., 2014). The lack of bitter pit reduction during 'Honeycrisp' CA storage may be due to different atmosphere composition and/or CA establishment protocols. The absence of an effect of CA storage on bitter pit incidence in orchard lots with low bitter pit incidence is consistent with Contreras et al. (2014) and DeEll et al. (2015). Anaerobiosis before cold storage has also resulted in decreased bitter pit development (Pesis et al., 2010), but the CA conditions imposed in the work reported here are unlikely to have created anaerobic conditions based on a low-oxygen limit of 0.33 $\mathrm{kPa} \mathrm{O}_{2}$ for 'Honeycrisp' at $10{ }^{\circ} \mathrm{C}$ (Wright et al., 2010). The reduction in bitter pit

Table 2. 'Honeycrisp' apple fruit quality and disorders 7 months after harvest, lot A for two harvest years.

\begin{tabular}{|c|c|c|c|c|c|c|c|c|c|c|c|c|c|c|c|}
\hline $\mathrm{Yr}$ & Atmosphere 1-MCP & $\begin{array}{l}\text { BP } \\
(\%)\end{array}$ & $\begin{array}{l}\text { PB } \\
(\%)\end{array}$ & $\begin{array}{c}\text { DFB } \\
(\%)\end{array}$ & $\begin{array}{c}\text { Cavity } \\
(\%)\end{array}$ & $\begin{array}{c}\text { TNCD } \\
(\%)\end{array}$ & $\begin{array}{l}\text { SSld } \\
(\%)\end{array}$ & $\begin{array}{l}\text { SB } \\
(\%)\end{array}$ & $\begin{array}{c}\text { Greasy } \\
(\%)\end{array}$ & $\begin{array}{l}\text { Peel } \\
\left({ }^{\circ} \mathrm{h}\right)\end{array}$ & $\begin{array}{l}\text { SSC } \\
(\%)\end{array}$ & $\begin{array}{l}\text { TA } \\
(\%)\end{array}$ & $\begin{array}{l}\text { Firm } \\
(\mathrm{N})\end{array}$ & $\begin{array}{c}\mathrm{C}_{2} \mathrm{H}_{4} \\
\left(\eta \mathrm{mol} \cdot \mathrm{g}^{-1} \cdot \mathrm{s}^{-1}\right)\end{array}$ & $\begin{array}{c}\mathrm{CO}_{2} \\
\left(\eta \mathrm{mol} \cdot \mathrm{g}^{-1} \cdot \mathrm{s}^{-1}\right)\end{array}$ \\
\hline \multirow{4}{*}{$\overline{1}$} & CA $1 \mathrm{~d}$ & 39 & $9 \mathrm{bc}$ & 1 & 0 & 39 & 0 & 0 & 0 & 99.4 & $14.8 \mathrm{a}$ & $0.507 \mathrm{ab}$ & 63.9 & 0.61 & $94 \mathrm{~b}$ \\
\hline & CA $1 \mathrm{~d}$ & 25 & $20 \mathrm{~b}$ & 0 & 0 & 25 & 0 & 0 & 0 & 99.4 & $14.7 \mathrm{a}$ & $0.534 \mathrm{a}$ & 60.8 & 0.06 & $47 \mathrm{c}$ \\
\hline & Air & 66 & $56 \mathrm{a}$ & 5 & 2 & 67 & 0 & 0 & 0 & 91.8 & $13.9 \mathrm{ab}$ & $0.418 \mathrm{~b}$ & 63.8 & 0.43 & $95 \mathrm{~b}$ \\
\hline & Atmosphere & $* * *$ & $* *$ & ** & NS & $* * *$ & NS & NS & NS & $* * *$ & $* * *$ & $* * *$ & NS & $* * *$ & **** \\
\hline \multirow[t]{7}{*}{2} & Control: CA $9 \mathrm{~d}$ & $39 \mathrm{a}$ & 0 & 10 & $0 \mathrm{~b}$ & $44 \mathrm{a}$ & 0 & 0 & 0 & 97.7 & $14.7 \mathrm{ab}$ & $0.382 \mathrm{~b}$ & 61.7 & $0.43 \mathrm{~b}$ & 74 \\
\hline & CA $1 \mathrm{~d}$ & $18 \mathrm{~b}$ & 0 & 1 & $0 \mathrm{~b}$ & $18 \mathrm{~b}$ & 0 & 0 & 3 & 94.0 & $15.4 \mathrm{a}$ & $0.370 \mathrm{~b}$ & 64.9 & $0.49 \mathrm{ab}$ & 81 \\
\hline & Air & $36 \mathrm{a}$ & 0 & 1 & $0 \mathrm{~b}$ & $37 \mathrm{a}$ & 0 & 0 & 30 & 91.2 & $14.3 \mathrm{~b}$ & $0.301 \mathrm{c}$ & 64.2 & $0.64 \mathrm{a}$ & 112 \\
\hline & 1-MCP: CA $9 \mathrm{~d}$ & $28 \mathrm{ab}$ & 17 & 7 & $9 \mathrm{a}$ & $38 \mathrm{a}$ & 3 & 0 & 3 & 97.2 & $14.1 \mathrm{~b}$ & $0.376 \mathrm{~b}$ & 56.4 & $0.22 \mathrm{c}$ & 51 \\
\hline & CA $1 \mathrm{~d}$ & $17 \mathrm{~b}$ & 10 & 7 & $4 \mathrm{ab}$ & $27 \mathrm{ab}$ & 0 & 0 & 0 & 98.2 & $15.5 \mathrm{a}$ & $0.441 \mathrm{a}$ & 65.3 & $0.06 \mathrm{c}$ & 51 \\
\hline & Air & $29 \mathrm{ab}$ & 9 & 0 & $0 \mathrm{~b}$ & $29 \mathrm{ab}$ & 0 & 0 & 34 & 90.9 & $15.0 \mathrm{a}$ & $0.355 b c$ & 67.0 & $0.45 \mathrm{~b}$ & 94 \\
\hline & Atmosphere & NS & NS & $* * *$ & NS & NS & NS & NS & ** & $* * *$ & $* * *$ & $* * *$ & NS & $* * *$ & $* * *$ \\
\hline
\end{tabular}

$\mathrm{BP}=$ bitter pit; $\mathrm{PB}=$ peel blotch; $\mathrm{DFB}=$ diffuse flesh browning; $\mathrm{TNCD}=$ total incidence of non-chilling disorders: bitter pit, diffuse flesh breakdown, cavities; $\mathrm{SSld}=$ soft scald $\mathrm{SB}=$ soggy breakdown; greasy = peel greasiness; firm = firmness; $\mathrm{CA}=$ controlled atmosphere; 1 -MCP $=1$-methylcyclopropene; $\mathrm{TA}=$ titratable acidity; SSC $=$ soluble solids content. Fruit were held at $10^{\circ} \mathrm{C}$ for $7 \mathrm{~d}$ and $3{ }^{\circ} \mathrm{C}$ thereafter. Fruit at $10^{\circ} \mathrm{C}$ were exposed to 0 or $4.2 \mu \mathrm{mol} \cdot \mathrm{m}^{-3} 1-\mathrm{MCP}$ for $16 \mathrm{~h}$ the day of receipt. Fruit were stored in air or a $\mathrm{CA}(3 \mathrm{k} \mathrm{Pa} \mathrm{O}$ for $2 \mathrm{~d}$, then $2 \mathrm{kPa} ; 0.5 \mathrm{kPa} \mathrm{CO}$ throughout $)$ imposed 1 or $9 \mathrm{~d}$ after receipt. 1-MCP $\times$ atmosphere means followed by different lower case letters are significantly different. $\mathrm{n}=72$ (year 1 ) or 108 (year 2) for disorders; $\mathrm{n}=18$ for peel ${ }^{\circ} \mathrm{h}$ and firmness; $\mathrm{n}=9$ for SSC and $\mathrm{TA} ; \mathrm{n}=4$ for $\mathrm{C}_{2} \mathrm{H}_{4}$ and $\mathrm{CO}_{2}$ production.

NS, *,***** Nonsignificant or significant main effects and interactions at $P<0.05,0.01$, or 0.001 , respectively. 
Table 3. 'Honeycrisp' apple fruit quality and disorders 7 months after harvest, lot B for two harvest years.

\begin{tabular}{|c|c|c|c|c|c|c|c|c|c|c|c|c|c|c|c|}
\hline Yr & Atmosphere 1-MCP & $\begin{array}{l}\text { BP } \\
(\%)\end{array}$ & $\begin{array}{l}\text { PB } \\
(\%)\end{array}$ & $\begin{array}{l}\text { DFB } \\
(\%)\end{array}$ & $\begin{array}{c}\text { Cavity } \\
(\%)\end{array}$ & $\begin{array}{c}\text { TNCD } \\
(\%)\end{array}$ & $\begin{array}{l}\text { SSld } \\
(\%)\end{array}$ & $\begin{array}{l}\text { SB } \\
(\%)\end{array}$ & $\begin{array}{c}\text { Greasy } \\
(\%)\end{array}$ & $\begin{array}{l}\text { Peel } \\
\left({ }^{\circ} \mathrm{h}\right)\end{array}$ & $\begin{array}{l}\text { SSC } \\
(\%)\end{array}$ & $\begin{array}{l}\text { TA } \\
(\%)\end{array}$ & $\begin{array}{l}\text { Firm } \\
(\mathrm{N})\end{array}$ & $\begin{array}{c}\mathrm{C}_{2} \mathrm{H}_{4} \\
\left(\eta \mathrm{mol} \cdot \mathrm{g}^{-1} \cdot \mathrm{s}^{-1}\right)\end{array}$ & $\begin{array}{c}\mathrm{CO}_{2} \\
\left(\eta \mathrm{mol} \cdot \mathrm{g}^{-1} \cdot \mathrm{s}^{-1}\right)\end{array}$ \\
\hline \multirow{5}{*}{$\overline{1}$} & CA $1 \mathrm{~d}$ & 8 & 3 & 1 & 6 & 14 & 0 & 0 & 0 & 99.4 & $11.8 \mathrm{a}$ & $0.341 \mathrm{a}$ & 58.9 & $0.55 \mathrm{~b}$ & 68 \\
\hline & Air & 7 & 0 & 0 & 4 & 11 & 6 & 0 & 0 & 92.8 & $10.9 \mathrm{~b}$ & $0.161 \mathrm{c}$ & 58.6 & $0.76 \mathrm{a}$ & 99 \\
\hline & CA $1 \mathrm{~d}$ & 6 & 6 & 0 & 13 & 17 & 0 & 0 & 0 & 99.4 & $11.7 \mathrm{a}$ & $0.322 \mathrm{a}$ & 56.8 & $0.05 \mathrm{c}$ & 44 \\
\hline & Air & 8 & 8 & 0 & 6 & 13 & 3 & 0 & 0 & 91.8 & $11.9 \mathrm{a}$ & $0.279 \mathrm{~b}$ & 56.8 & $0.54 \mathrm{~b}$ & 80 \\
\hline & Atmosphere & NS & NS & NS & $* *$ & $* *$ & NS & NS & NS & $* * *$ & $* * *$ & $* * *$ & NS & $* * *$ & $* * *$ \\
\hline \multirow[t]{7}{*}{2} & Control: CA $9 \mathrm{~d}$ & 11 & 0 & 1 & $13 \mathrm{a}$ & 22 & 9 & 19 & $42 \mathrm{~b}$ & 94.9 & $13.2 \mathrm{ab}$ & 0.325 & 61.1 & $0.54 \mathrm{a}$ & $73 \mathrm{ab}$ \\
\hline & CA $1 \mathrm{~d}$ & 3 & 0 & 0 & $7 \mathrm{ab}$ & 10 & 11 & 14 & $0 \mathrm{c}$ & 96.4 & $12.9 \mathrm{~b}$ & 0.335 & 60.7 & $0.52 \mathrm{a}$ & $62 \mathrm{~b}$ \\
\hline & Air & 11 & 0 & 0 & $0 \mathrm{~b}$ & 11 & 3 & 0 & $94 \mathrm{a}$ & 92.3 & $12.6 \mathrm{~b}$ & 0.251 & 61.8 & $0.65 \mathrm{a}$ & $91 \mathrm{a}$ \\
\hline & 1-MCP: CA 9 d & 13 & 0 & 0 & $3 \mathrm{ab}$ & 13 & 8 & 11 & $0 \mathrm{c}$ & 97.5 & $13.7 \mathrm{a}$ & 0.373 & 59.6 & $0.10 \mathrm{~b}$ & $34 \mathrm{c}$ \\
\hline & CA $1 \mathrm{~d}$ & 1 & 0 & 0 & $6 \mathrm{ab}$ & 1 & 14 & 19 & $0 \mathrm{c}$ & 92.4 & $13.5 \mathrm{ab}$ & 0.346 & 57.2 & $0.04 \mathrm{~b}$ & $45 \mathrm{bc}$ \\
\hline & Air & 4 & 0 & 0 & $6 \mathrm{ab}$ & 4 & 6 & 6 & $50 \mathrm{~b}$ & 85.2 & $13.5 \mathrm{ab}$ & 0.288 & 59.4 & $0.48 \mathrm{a}$ & $77 \mathrm{ab}$ \\
\hline & Atmosphere & ** & NS & NS & NS & * & * & ** & $* * *$ & $* *$ & $* * *$ & *** & NS & $* * *$ & $* * *$ \\
\hline
\end{tabular}

$\mathrm{BP}=$ bitter pit; $\mathrm{PB}=$ peel blotch; $\mathrm{DFB}=$ diffuse flesh browning; $\mathrm{TNCD}=$ total incidence of non-chilling disorders: bitter pit, diffuse flesh breakdown, cavities; $\mathrm{SSld}=$ soft scald $\mathrm{SB}=$ soggy breakdown; greasy = peel greasiness; firm = firmness; $\mathrm{CA}=$ controlled atmosphere; 1 -MCP $=1$-methylcyclopropene; $\mathrm{TA}=$ titratable acidity; $\mathrm{SSC}=$ soluble solids content. Fruit were held at $10^{\circ} \mathrm{C}$ for $7 \mathrm{~d}$ and $3{ }^{\circ} \mathrm{C}$ thereafter. Fruit at $10^{\circ} \mathrm{C}$ were exposed to 0 or $4.2 \mu \mathrm{mol} \cdot \mathrm{m}^{-3} 1-\mathrm{MCP}$ for $16 \mathrm{~h}$ the day of receipt. Fruit were stored in air or a CA $\left(3 \mathrm{k} \mathrm{Pa} \mathrm{O}_{2}\right.$ for $2 \mathrm{~d}$, then $2 \mathrm{kPa} ; 0.5 \mathrm{kPa} \mathrm{CO}$ throughout $)$ imposed 1 or $9 \mathrm{~d}$ after receipt. 1-MCP $\times$ atmosphere means followed by different lower case letters are significantly different. $\mathrm{n}=72$ (year 1 ) or 108 (year 2) for disorders; $\mathrm{n}=18$ for peel ${ }^{\circ} \mathrm{h}$ and firmness; $\mathrm{n}=9$ for SSC and $\mathrm{TA} ; \mathrm{n}=4$ for $\mathrm{C}_{2} \mathrm{H}_{4}$ and $\mathrm{CO}_{2}$ production.

Ns, $*, * *, * * *$ Nonsignificant or significant main effects and interactions at $P<0.05,0.01$, or 0.001 , respectively.

Table 4. 'Honeycrisp' apple fruit quality and disorders 7 months after harvest, lots $\mathrm{C}$, D, and E for one harvest year.

\begin{tabular}{|c|c|c|c|c|c|c|c|c|c|c|c|c|c|c|}
\hline Lot & Atmosphere 1-MCP & $\begin{array}{l}\text { BP } \\
(\%)\end{array}$ & $\begin{array}{l}\text { PB } \\
(\%)\end{array}$ & $\begin{array}{l}\text { DFB } \\
(\%)\end{array}$ & $\begin{array}{c}\text { Cavity } \\
(\%)\end{array}$ & $\begin{array}{c}\text { TNCD } \\
(\%)\end{array}$ & $\begin{array}{l}\text { SSld } \\
(\%)\end{array}$ & $\begin{array}{l}\text { SB } \\
(\%)\end{array}$ & $\begin{array}{c}\text { Greasy } \\
(\%)\end{array}$ & $\begin{array}{l}\text { Peel } \\
\left({ }^{\circ} \mathrm{h}\right)\end{array}$ & $\begin{array}{l}\mathrm{SSC} \\
(\%)\end{array}$ & $\begin{array}{l}\text { TA } \\
(\%)\end{array}$ & $\begin{array}{l}\text { Firm } \\
(\mathrm{N})\end{array}$ & $\begin{array}{c}\text { IEC } \\
\left(\mathrm{mmol} \cdot \mathrm{m}^{-3}\right)\end{array}$ \\
\hline \multirow[t]{9}{*}{$\overline{\mathrm{C}}$} & Control: CA 9 d & 9 & 0 & 0 & 2 & 11 & 0 & 0 & 1 & $90.4 \mathrm{c}$ & $13.3 \mathrm{bc}$ & $0.459 \mathrm{~b}$ & 57.4 & $7.5 \mathrm{ab}$ \\
\hline & CA $1 \mathrm{~d}$ & 7 & 0 & 2 & 2 & 9 & 0 & 0 & 0 & $99.8 \mathrm{a}$ & $13.3 \mathrm{bc}$ & $0.496 \mathrm{ab}$ & 58.7 & $6.7 \mathrm{~b}$ \\
\hline & Air & 10 & 0 & 0 & 0 & 10 & 0 & 0 & 8 & $87.6 \mathrm{c}$ & $13.1 \mathrm{c}$ & $0.388 \mathrm{c}$ & 55.6 & $9.2 \mathrm{a}$ \\
\hline & 1-MCP: CA 9 d & 6 & 3 & 0 & 1 & 6 & 0 & 0 & 0 & $98.4 \mathrm{ab}$ & $13.6 \mathrm{bc}$ & $0.492 \mathrm{ab}$ & 54.7 & $0.14 \mathrm{c}$ \\
\hline & CA $1 \mathrm{~d}$ & 4 & 1 & 1 & 6 & 10 & 0 & 0 & 0 & $99.2 \mathrm{abc}$ & $14.2 \mathrm{a}$ & $0.514 \mathrm{a}$ & 53.8 & $0.24 \mathrm{c}$ \\
\hline & Air & 15 & 5 & 0 & 0 & 15 & 0 & 0 & 6 & $83.3 \mathrm{c}$ & $13.8 \mathrm{ab}$ & $0.484 \mathrm{ab}$ & 57.0 & $5.6 \mathrm{~b}$ \\
\hline & Atmosphere & $*$ & NS & NS & $* *$ & NS & NS & NS & $* * *$ & $* * *$ & $*$ & $* * *$ & NS & $* * *$ \\
\hline & $1-\mathrm{MCP}$ & NS & $*$ & NS & NS & NS & NS & NS & NS & NS & $* * *$ & $* * *$ & NS & $* * *$ \\
\hline & Atmosphere $\times 1$-MCP & NS & NS & NS & NS & NS & NS & NS & NS & $* *$ & $*$ & $* * *$ & NS & $* * *$ \\
\hline \multirow[t]{9}{*}{$\mathrm{D}$} & Control: CA 9 d & 33 & $0 \mathrm{c}$ & 0 & 1 & 34 & 1 & 4 & 0 & $101 \mathrm{a}$ & $12.5 \mathrm{~b}$ & $0.396 \mathrm{bc}$ & 58.7 & $7.0 \mathrm{ab}$ \\
\hline & CA $1 \mathrm{~d}$ & 23 & $1 \mathrm{c}$ & 1 & 0 & 24 & 1 & 0 & 0 & $102 \mathrm{a}$ & $12.6 \mathrm{~b}$ & $0.423 \mathrm{~b}$ & 56.5 & $7.1 \mathrm{ab}$ \\
\hline & air & 41 & $0 \mathrm{c}$ & 0 & 0 & 41 & 0 & 3 & 0 & $96.8 \mathrm{ab}$ & $11.7 \mathrm{c}$ & $0.318 \mathrm{~d}$ & 58.3 & $8.7 \mathrm{a}$ \\
\hline & 1-MCP: CA 9 d & 19 & $8 \mathrm{~b}$ & 0 & 2 & 21 & 4 & 6 & 0 & $99.4 \mathrm{a}$ & $13.0 \mathrm{ab}$ & $0.479 \mathrm{a}$ & 58.3 & $0.08 \mathrm{c}$ \\
\hline & CA $1 \mathrm{~d}$ & 14 & $10 \mathrm{~b}$ & 0 & 2 & 16 & 1 & 3 & 0 & $103 \mathrm{a}$ & $13.3 \mathrm{a}$ & $0.500 \mathrm{a}$ & 57.0 & $0.05 \mathrm{c}$ \\
\hline & air & 33 & $26 \mathrm{a}$ & 0 & 0 & 33 & 4 & 0 & 5 & $90.1 \mathrm{~b}$ & $13.2 \mathrm{a}$ & $0.370 \mathrm{c}$ & 57.4 & $6.5 \mathrm{~b}$ \\
\hline & Atmosphere & $* * *$ & $* * *$ & NS & NS & $* * *$ & NS & $*$ & NS & $* * *$ & $* * *$ & $* * *$ & NS & $* * *$ \\
\hline & $1-\mathrm{MCP}$ & $*$ & $* * *$ & NS & NS & $* *$ & $*$ & NS & NS & NS & $* * *$ & $* * *$ & NS & $* * *$ \\
\hline & Atmosphere $\times 1$-MCP & NS & $* * *$ & NS & NS & NS & NS & NS & NS & $* * *$ & $* * *$ & NS & NS & $* * *$ \\
\hline \multirow[t]{9}{*}{$\mathrm{E}$} & Control: CA 9 d & 11 & 3 & 3 & 0 & 15 & 3 & 0 & 0 & $88 \mathrm{bc}$ & $12.5 \mathrm{c}$ & $0.348 \mathrm{c}$ & 55.2 & $5.0 \mathrm{ab}$ \\
\hline & CA $1 \mathrm{~d}$ & 6 & 2 & 0 & 0 & 6 & 2 & 1 & 0 & $94 \mathrm{ab}$ & $13.2 \mathrm{ab}$ & $0.393 \mathrm{bc}$ & 53.4 & $4.9 \mathrm{ab}$ \\
\hline & Air & 18 & 0 & 0 & 0 & 18 & 0 & 0 & 7 & $89 \mathrm{bc}$ & $12.6 \mathrm{bc}$ & $0.290 \mathrm{~d}$ & 55.6 & $6.3 \mathrm{a}$ \\
\hline & 1-MCP: CA 9 d & 8 & 5 & 0 & 1 & 10 & 0 & 0 & 0 & $98 \mathrm{a}$ & $12.9 \mathrm{bc}$ & $0.367 \mathrm{bc}$ & 53.4 & $0.36 \mathrm{c}$ \\
\hline & CA $1 \mathrm{~d}$ & 5 & 4 & 3 & 2 & 9 & 1 & 0 & 0 & $96 \mathrm{ab}$ & $13.7 \mathrm{a}$ & $0.457 \mathrm{a}$ & 57.0 & $0.06 \mathrm{c}$ \\
\hline & Air & 9 & 4 & 0 & 0 & 9 & 2 & 0 & 12 & $89 \mathrm{bc}$ & $13.2 \mathrm{ab}$ & $0.411 \mathrm{ab}$ & 55.2 & $3.2 \mathrm{~b}$ \\
\hline & Atmosphere & $*$ & NS & NS & NS & NS & NS & NS & $* * *$ & NS & $* *$ & $* * *$ & NS & $* * *$ \\
\hline & $1-\mathrm{MCP}$ & NS & NS & NS & NS & NS & NS & NS & NS & $* * *$ & $* * *$ & $* * *$ & NS & $* * *$ \\
\hline & Atmosphere $\times 1$-MCP & NS & NS & NS & NS & NS & NS & NS & NS & $* * *$ & $* *$ & $* * *$ & NS & NS \\
\hline
\end{tabular}

$\mathrm{BP}=$ bitter pit; $\mathrm{PB}=$ peel blotch; $\mathrm{DFB}=$ diffuse flesh browning; TNCD = total incidence of non-chilling disorders: bitter pit, diffuse flesh breakdown, cavities; $\mathrm{SSld}=$ soft scald; $\mathrm{SB}=$ soggy breakdown; greasy = peel greasiness; firm = firmness; IEC = internal ethylene concentration; $\mathrm{CA}=$ controlled atmosphere; 1 -MCP = 1-methylcyclopropene; TA $=$ titratable acidity; $\mathrm{SSC}=$ soluble solids content. Fruit were held at $10{ }^{\circ} \mathrm{C}$ for $7 \mathrm{~d}$ and $3{ }^{\circ} \mathrm{C}$ thereafter. Fruit at $10{ }^{\circ} \mathrm{C}$ were exposed to 0 or $4.2 \mu \mathrm{mol} \cdot \mathrm{m}^{-3} 1-\mathrm{MCP}$ for $16 \mathrm{~h}$ the day of receipt. Fruit were stored in air or a $\mathrm{CA}\left(3 \mathrm{k} \mathrm{Pa} \mathrm{O}_{2}\right.$ for $2 \mathrm{~d}$, then $2 \mathrm{kPa}$; $0.5 \mathrm{kPa} \mathrm{CO}_{2}$ throughout $)$ imposed $1 \mathrm{or} 9 \mathrm{~d}$ after receipt. 1 -MCP $\times$ atmosphere means followed by different lower case letters are significantly different. $\mathrm{n}=108$ for disorders; $\mathrm{n}=18$ for peel ${ }^{\circ} \mathrm{h}$ and firmness; $\mathrm{n}=9$ for SSC and TA; $n=10$ for internal ethylene content.

Ns, ${ }^{*}, * * * * * *$ Nonsignificant or significant main effects and interactions at $P<0.05,0.01$, or 0.001 , respectively.

development following 1-MCP application at harvest or in response to CA storage indicates that limited ethylene action resulting from 1-MCP treatment (Sisler and Blankenship, 1996) and/or a low- $\mathrm{O}_{2}$ environment (Burg and Burg, 1965) soon after harvest may contribute to reduced bitter pit development.
These and previous results (Hewett, 1984; Sharples, 1982; Webster and Forsyth, 1979) indicate a possible role for ethylene in bitter pit development. Reduced bitter pit incidence following 1-MCP treatment and/or CA storage was most evident in lots with high disorder incidence in control fruit stored in air.
Significant main effects for 1-MCP and atmosphere indicate that both factors can influence bitter pit development. When main effects for 1-MCP and CA were significant but the interaction was not significant, the effect of each independent variable was consistent for all levels of the second independent variable. In 
those instances (i.e., lot $\mathrm{A}$ in both years), bitter pit incidence decreased when fruit was stored in CA compared with air, and an additional incidence decrease resulted from imposing CA during temperature conditioning. Incidence decreased further when fruit stored in the same atmosphere had been previously treated with 1-MCP. While CA and/or 1MCP reduced but did not prevent bitter pit, the high commercial value of 'Honeycrisp' provides incentive for postharvest management that reduces this source of fruit loss in the commercial supply chain.

Reduced bitter pit incidence following $1-\mathrm{MCP}$ treatment is consistent with results for 'Bramley's Seedling' (Mirzaee et al., 2015) and 'Granny Smith' (Calvo and Candan, 2010) but contrasts with 'Golden Delicious' where 1-MCP before storage enhanced bitter pit development (Gago et al., 2015). Differential 1-MCP impacts on bitter pit development may be due to differences in cultivars or 1-MCP application timing (day of harvest for 'Bramley's Seedling', 'Granny Smith', and 'Honeycrisp', and $3 \mathrm{~d}$ after harvest for 'Golden Delicious') or other unknown factors. The variable bitter pit response is consistent with other aspects of apple fruit ripening for which 1-MCP impacts are dependent on multiple factors including cultivar, 1-MCP treatment protocol, storage conditions, and storage duration (DeEll et al., 2002; Watkins et al., 2000).

Peel blotch occurred in both control and 1-MCP-treated fruit but incidence was often higher for 1-MCP-treated fruit. Peel blotch incidence was always lower compared with bitter pit incidence. In fact, all fruit that had peel blotch also had bitter pit, therefore peel blotch was not an additional source of loss. The exclusive presence of peel blotch in the subset of fruit with bitter pit suggests a possible link between the two disorders, particularly when ethylene action has been inhibited by $1-\mathrm{MCP}$. The metabolic events that result in bitter pit may be altered following 1-MCP treatment such that disorder symptom development is more likely to progress to peel blotch. Zanella et al. (2005) previously reported bitter pit damage was more pronounced but incidence was unchanged in 1-MCP-treated fruit compared with controls. Calvo and Candan (2010) reported that 1-MCP-treated 'Granny Smith' apples from an early harvest had increased lenticel blotch incidence relative to control fruit; however, lenticel blotch symptoms are localized around lenticels while peel blotch reported here is not lenticel specific.

Conditioning 'Honeycrisp' fruit at a higher than final storage temperature for a short period after harvest reduces CI, but this protocol can exacerbate bitter pit development (Watkins et al., 2004). Reports documenting 'Honeycrisp' fruit response to CA storage indicate a risk of internal disorders similar to $\mathrm{CO}_{2}$ injury (Contreras et al., 2014; DeEll et al., 2015, 2016; Watkins and Nock, 2012). Under the conditions of these experiments, the lowoxygen CA set point ( $3 \mathrm{kPa}$ decreased to $2 \mathrm{kPa}$ after 2 d) was above the low-oxygen limit at
$10{ }^{\circ} \mathrm{C}(0.33 \mathrm{kPa})$ reported for 'Honeycrisp' (Wright et al., 2010), therefore DFB and cavities are unlikely a result of low-oxygen injury. Application of diphenylamine before imposition of CA provides protection from $\mathrm{CA}$ injury development (Contreras et al., 2014) and may be a means to reduce the risk of CA injury when using a postharvest protocol with $\mathrm{CA}$ established during conditioning.

The use of 1-MCP and/or CA resulted in enhanced fruit quality compared with untreated fruit stored in air including reduced peel greasiness and yellow color development and enhanced retention of SSC and TA, consistent with previous reports for this cultivar (Contreras et al., 2014; DeEll et al., 2015; DeLong et al., 2006; Watkins and Nock, 2012). These results are consistent with slower fruit ripening reflected in lower IEC or ethylene production and lower respiration rate. In a number of instances, rapid $\mathrm{CA}$ with or without previous 1-MCP treatment enhanced this fruit response compared with CA initiated later, providing additional reduction in fruit ripening and potential benefit in quality retention after storage. Rapid establishment of CA conditions for apples has long been demonstrated to enhance preservation of fruit quality of some cultivars compared with delayed CA establishment (Fidler and North, 1967; Lau, 1982).

Reduction of fruit physiological disorders that develop during storage contributes to enhanced orchard productivity and energy use efficiency in the postharvest supply chain. The postharvest protocols evaluated in this study are applicable without development of additional physical resources at commercial apple warehouses currently operating CA facilities. While an enhanced risk of physiological disorder development due to CA storage was not observed during this study, regardless of when CA was established, it to what extent risk of injury from CA imposed during or after conditioning exists within the larger population of 'Honeycrisp' fruit from multiple orchards and production areas.

\section{Literature Cited}

Bedford, D. 2001. Honeycrisp. Compact Fruit Tree 34:98-99.

Biggs, A.R. and G.M. Peck. 2015. Managing bitter pit in 'Honeycrisp' apples grown in the mid-Atlantic United States with foliar applied calcium chloride and some alternatives. HortTechnology 25:385-391.

Burg, S.P. and E.A. Burg. 1965. Ethylene action and ripening of fruits. Science 148:1190-1196.

Calvo, G. and A.P. Candan. 2010. 1-methylcyclopropene (1-MCP) affects physiological disorders in 'Granny Smith' apples depending on maturity stage. Acta Hort. 857:63-70.

Contreras, C., N. Alsmairat, and R. Beaudry. 2014. Prestorage conditioning and diphenylamine improve resistance to controlled-atmosphererelated injury in 'Honeycrisp' apples. HortScience 49:76-81.

DeEll, J.R. 2010. SmartFresh (1-MCP) and storage of Honeycrisp apples. Compact Fruit Grower 43:20-23.

DeEll, J.R. and B. Ehsani-Moghaddam. 2010. Preharvest 1-methylcyclopropene treatment reduces soft scald in 'Honeycrisp' apples during storage. HortScience 45:414-417.

DeEll, J.R., B. Ehsani-Moghaddam, A.J. Bowen, and I. Lesschaeve. 2015. Effects of 1-methylcyclopropene and controlled atmosphere storage on the quality of 'Honeycrisp' apples. Acta Hort. 1071:483-488.

DeEll, J.R., G.B. Lum, and B. Ehsani-Moghaddam. 2016. Effects of delayed controlled atmosphere storage on disorder development in 'Honeycrisp' apples. Can. J. Plant Sci. 96:621-629.

DeEll, J.R., D.P. Murr, M.D. Porteous, and H.P. Rupasinghe. 2002. Influence of temperature and duration of 1-methylcyclopropene (1MCP) treatment on apple quality. Postharvest Biol. Technol. 24:349-353.

DeLong, J.M., R.K. Prange, P.A. Harrison, G.C. Embree, S.D. Nichols, and H. Wright. 2006. The influence of crop-load, delayed cooling and storage atmosphere on post-storage quality of 'Honeycrisp' apples. J. Hort. Sci. Biotechnol. 81:391-396.

Ferguson, I.B. and C.B. Watkins. 1989. Bitter pit in apple fruit, p. 289-355. In: J. Janick (ed.). Horticultural Reviews. Timber Press, Portland, OR.

Fidler, J.C. and C.J. North. 1967. The effect on apples of the rate of establishment of conditions of storage, p. 10-12. Ann. Rep. Ditton Lab. 1966-67. Agri. Res. Council, London, UK.

Gago, C.M.L., A.C. Guerreiro, G.M. Miguel, T. Panagopoulos, C. Sánchez, and M.D.C. Antunes. 2015. Effect of harvest date, and 1-MCP (SmartFresh ${ }^{\mathrm{TM}}$ ) treatment on 'Golden Delicious' apple cold storage physiological disorders. Postharvest Biol. Technol. 110:77-85.

Hanrahan, I. 2012. Starch iodine index for Honeycrisp. 15 May 2016. <http://www.treefruitresearch. com/resources-a-downloads/starch-iodine-indexfor-honeycrisp >

Hewett, E.W. 1984. Bitter pit reduction in 'Cox's Orange Pippin' apples by controlled and modified atmosphere storage. Sci. Hort. 23:59-66.

Hunter, R.S. and R.W. Harold. 1987. The measurement of appearance. 2nd ed. Wiley \& Sons, New York, NY.

Lachapelle, M., G. Bourgeois, J. DeEll, K.A. Stewart, and P. Séguin. 2013. Modeling the effect of preharvest weather conditions on the incidence of soft scald in 'Honeycrisp' apples. Postharvest Biol. Technol. 85:57-66.

Lau, O.L. 1982. Use of rapid CA to maximize storage life of apples, p. 201-210. In: D.G. Richardson and M. Meheriuk (eds.). Controlled atmospheres for storage and transport of perishable agricultural commodities. Timber Press, Beaverton, OR.

Lum, G.B., C.J. Brikis, K.L. Deyman, S. Subedi, J.R. DeEll, B.J. Shelp, and G.G. Bozzo. 2016. Pre-storage conditioning ameliorates the negative impact of 1-methylcyclopropene on physiological injury and modifies the response of antioxidants and $\gamma$-aminobutyrate in 'Honeycrisp' apples exposed to controlled-atmosphere conditions. Postharvest Biol. Technol. 116:115-126.

Lumpkin, C., J.K. Fellman, D.R. Rudell, and J. Mattheis. 2014. 'Scarlett Spur Red Delicious' apple volatile production accompanying physiological disorder development during low $\mathrm{pO}_{2}$ controlled atmosphere storage. J. Agr. Food Chem. 62:1741-1754.

McAlpine, D. 1912. The past history and present position of the bitter pit question, p. 111-117. First Progr. Rep. Commonw. Aust., Melbourne, Australia,

Mirzaee, M., D. Rees, R.J. Colgan, and M.S. Tully. 2015. Diagnosing bitter pit in apple during storage by chlorophyll fluorescence as a nondestructive tool. Acta Hort. 1079:235-242.

Moran, R.E., J.R. DeEll, and W. Halteman. 2009. Effects of preharvest precipitation, air temperature, 
and humidity on the occurrence of soft scald in 'Honeycrisp' apples. HortScience 44:16451647.

Peryea, F.J., G.H. Neilsen, and D. Faubion. 2007. Start-timing for calcium chloride spray programs influences fruit calcium and bitter pit in 'Braeburn' and 'Honeycrisp' apples. J. Plant Nutr. 30:1213-1227.

Pesis, E., S.E. Ebeler, S.T. de Freitas, M. Padda, and E.J. Mitcham. 2010. Short anaerobiosis period prior to cold storage alleviates bitter pit and superficial scald in Granny Smith apples. J. Sci. Food Agr. 90:2114-2123.

Prange, R., J. Delong, D. Nichols, and P. Harrison. 2011. Effect of fruit maturity on the incidence of bitter pit, senescent breakdown, and other post-harvest disorders in 'Honeycrisp' TM apple. J. Hort. Sci. Biotechnol. 86:245-248.

Robinson, T. and S. Lopez. 2012. Crop load affects 'Honeycrisp' fruit quality more than nitrogen, potassium, or irrigation. Acta Hort. 940:529-538.

Rosenberger, D., J. Schupp, S. Hoying, L. Cheng, and C.B. Watkins. 2004. Controlling bitter pit in 'Honeycrisp' apples. HortTechnology 14: 342-349.

Rosenberger, D., J. Schupp, C. Watkins, K. Iungerman, S. Hoying, D. Straub, and L. Cheng. 2001. Honeycrisp: Promising profit maker or just another problem child? N.Y. Fruit Quarterly 9:9-13.

Sharples, R.O. 1982. Effects of ultra-low oxygen conditions on the storage quality of English Cox's Orange Pippin apples, p. 131-138. Symposium Series - Oregon State University, Corvallis, OR.

Sisler, E.C. and S.M. Blankenship. 1996. Method of counteracting an ethylene response in plants U.S. patent no. 5,518,988. U.S. Patent Office, Washington, DC

Telias, A., E. Hoover, C. Rosen, D. Bedford, and D. Cook. 2006. The effect of calcium sprays and fruit thinning on bitter pit incidence and calcium content in 'Honeycrisp' apple. J. Plant Nutr. 29:1941-1957.

Tong, C. 2016. Honeycrisp apple research results. 10 July 2016. <http://smfarm.cfans.umn.edu/ honeycrisp-results $>$.

Warner, G. 2012. How long can this last? GoodFruit Grower. 10 July 2016. <http://www.goodfruit. com/how-long-can-this-last/>.

Watkins, C.B., M. Erkan, J.F. Nock, K.A. Iungerman, R.M. Beaudry, and R.E. Moran. 2005. Harvest date effects on maturity, quality, and storage disorders of 'Honeycrisp' apples. HortScience 40:164-169.

Watkins, C.B. and J.F. Nock. 2012. Controlledatmosphere storage of 'Honeycrisp' apples. HortScience 47:886-892.
Watkins, C.B., J.F. Nock, and B.D. Whitaker. 2000. Responses of early, mid and late season apple cultivars to postharvest application of 1-methylcyclopropene (1-MCP) under air and controlled atmosphere storage conditions. Postharvest Biol. Technol. 19:17-32.

Watkins, C., J. Nock, S. Weis, S. Jayanty, and R. Beaudry. 2004. Storage temperature, diphenylamine, and prestorage delay effects on soft scald, soggy breakdown and bitter pit of 'Honeycrisp' apples. Postharvest Biol. Technol. 32:213-221

Webster, D.H. and R.F. Forsyth. 1979. Partial control of bitter pit in Northern Spy apples with a post-harvest dip in calcium chloride solution. Can. J. Plant Sci. 59:717-723.

Wright, H., J. DeLong, P.A. Harrison, A.H.L.A.N. Gunawardena, and R. Prange. 2010. The effect of temperature and other factors on chlorophyll a fluorescence and the lower oxygen limit in apples (Malus domestica). Postharvest Biol. Technol. 55:21-28.

Zanella, A., M. Cecchinel, O. Rossi, P. Cazzanelli, and A. Panarese. 2005. Effects of the postharvest treatment with 1-methylcyclopropene (1-MCP) on the preservation of South-Tyrolean (Italy) apple quality during storage. Laimburg J. 2:6-26. 